team consisting of the heads of each Department and the Provincial Commissioner. Technical officers will be stationed with them. For some years efforts will be concentrated on these districts, but as success is obtained operations will be extended into the other districts of the area and eventually, it is hoped, cover the whole Territory. It is estimated that the Development Centres and Areas will cost $f_{\mathrm{I}, 500,000}$ over ten years and that $£ 450,000$ is required for the first three years; the latter sum is sufficient to permit the schemes to prove themselves and to show whether or not they give value for money spent.

No detailed programme is given for rural development, the object of which is to make the Africans healthy, wealthy, and wise. Government is prepared to give all assistance in its power, but it looks to the Native Authorities to suggest schemes of progress, under the stimulus (it should be added) of the Development Officers. The fatal error harboured in the average African's mind that progress comes, not from his own efforts, but from Government alone, must be extirpated. 'It must be established at the beginning of the programme that the African must progress on his own feet and will not be carried by Government. When any tribe or social unit is prepared to make strenuous efforts to improve itself the entire Government organization should be available to help it, but nothing should be done for the people which they are capable of doing for themselves.'

These ideas are elaborated in a remarkable memorandum by Mr. J. S. Moffat, the Commissioner for Native Development. 'Our aim', he writes, ' is to assist in the evolution of an African civilisation and not to impose an imitation European one.' The evolutionary process must emerge from the people themselves. Our aim must not be to develop the African but to assist him to develop himself. The flow of ideas from the villages upwards (through the Native Authorities and provincial teams) is the most important factor in development and must be encouraged in every way possible. Provision must also be made for the initiation of schemes by European officers, but in such cases the Native Authorities should sift all schemes involving social change and if necessary modify them to fit into the social structure of their people. We have no right to determine what is good for the African and then to use our power to see that he swallows it. Mr. Moffat realizes full well the immensity of his task and the obstacles his teams of workers will have to surmount; their main difficulty lies in the fact of the African's inertia: the lack of a driving force to carry forward a programme of social betterment. But he will travel hopefully.

\title{
A Development Plan for Uganda
}

DR. E. B. Worthington's plan is prefaced by a refreshingly candid survey of the situation by the Governor, Sir J. H. Hall. Development by means of European plantations is not to be thought of, because the land is held in trust for the Africans; collective farming on the Russian model is also ruled out because it would involve regimentation and dragooning; Uganda is, and for the present must remain, primarily a country of peasant agriculture. But 'speaking generally, and judging by European standards, the Africans of Uganda are indolent, ignorant, irresponsible'. The indolence is not incurable seeing that it is in large measure attributable to malnutrition and debilitation from disease. But-and this is noted as a very disturbing fact-administrators have failed to eradicate the belief that physical labour is socially degrading. An inefficient labour force; a rapidly increasing population; loss in fertility of much of the land; the ever advancing menace of tsetse: all these things have to be reckoned with in any planning scheme. Not a few people are convinced that the only way of carrying to success such schemes as have been put forth in Uganda and elsewhere is the way of compulsion. Dr. Worthington seems to agree that some degree of compulsion 'perhaps equivalent to that which is applied in Britain to-day', will be necessary.

The fundamental problem as he sees it is the problem of balance between production and population. The average standard of living cannot rise and public services cannot 
expand unless production increases at a rate greater than population. The 4 million people of Uganda will, it is guessed, increase to ro million in half a century and by then the productive capacity of the soil will be used to its fullest extent. Thereafter, if over-population is to be avoided, it will be necessary for the factors which lead to stabilization of population to have their effect. During the next ten years, while maintaining steady improvement in social services, the prime object should be a concentration on productive effort to ensure that production increases rapidly, at a rate much higher than population. After ten years, the way will be open for establishing greatly improved social services, including health and education, which in the early stages tend to accelerate the rate of increase of population but in advanced stages tend to cause stabilization.

So Dr. Worthington focuses attention on the next ten years and on production. Uganda's greatest asset is the large expanse of land and water which has not yet been utilized. The problem he has to solve is how to bring unused or unusable land into use and how to increase the African's output per head. The funds available for development amount to $£_{1} 6$ millions, including $£^{2 \frac{1}{2}}$ millions from the Colonial Development and Welfate Fund, grants from revenue, surplus balances, and loans. The schemes here presented are impressive in their comprehensiveness, covering almost every imaginable facet of existence. Of very special interest are the so-called Pilot Schemes. These differ in some respects from the Development Centres and Areas of Northern Rhodesia but are like them in the selection of districts for concentrated effort and experiment for the ultimate benefit of the whole territory. Eight possible areas are suggested, each of about 500 square miles, underpopulated or entirely without population on account of the tsetse; and it is proposed that south Busoga, once called The Garden of Uganda, should be the first to be developed. Each would be started as a government estate employing paid labour; and after five years of intensive effort the land (except for a government revenue-producing farm of about I0,000 acres) would be handed over to native farmers who would still be under European supervision. Initially about 100 families would be admitted, but ultimately 6,000 families would be distributed in the capital, villages, and agricultural settlements. If 5,000 of these were on the land (the remainder employed in other capacities) each would have about fifty acres. The government farm would be given up to exportable crops. Social services would include a central hospital, health centres, and schools, including a post-primary agricultural school in each area. "The question may arise whether the whole educational system might be provided directly by Government without using the agency of missions.' A team of Europeans would be in close control of each area for perhaps the first ten years. A million pounds is allocated to these Pilot Areas.

It will have been gathered that Dr. Worthington places all emphasis upon production. $\mathrm{He}$ is of the opinion that there has been a tendency in Uganda for health and education services to outrun others too fast; and he is unable to recommend more than a small increase of expenditure on them. It is noted that the educational system at present makes little provision for fitting pupils to take useful places in society. Some changes are proposed. Academic secondary education cannot stand still; but it is proposed to inaugurate a network of agricultural and technical post-primary schools to form an alternative to it-practical schools for boys and girls of about twelve to sixteen years. 'A drastic change is required to eradicate the idea that agriculture is women's work. If present ideas on this subject continue there is little doubt that the development of the Baganda and other Bantu peoples will soon be outpaced by the more hardworking Nilotic tribes of the north.' Emphasis is laid on education of girls because, for one thing, women rather than men control the birthrate. 'When women want and can obtain things other than children, the first stage towards stability of population will have been gained.'

Sir Douglas G. Harris, who since 1920 has had wide experience as an irrigation expert 
in India, Kenya, Palestine, and Cyprus, has been appointed Development Commissioner in Uganda.

\section{South African Native Affairs}

THE Union Native Affairs Department, a government within a government, has under its care a population of more than 7 million souls-more than two-thirds of the total inhabitants of the country. It carries a heavy burden of responsibility and is freely criticized from two quarters: by those who think it does too much and by those who think it does too little. It is, in fact, more liberal in its administration than Parliament is in its legislation. The Social and Economic Planning Council, in its Report (No. 9) on the Native Reserves, judiciously sums up the Department's achievements in the reserves:

'Apart from the minimum requirements of maintaining peace and order, which, on the whole, has been well done, it has in recent years become more definitely a welfare department; it has made serious efforts to improve Native agriculture and to encourage markets; it has co-operated willingly and effectively in the extension of educational facilities in the Reserves; it has taken a growing interest in social welfare projects in these areas. In its hands has lain the heavy task of adjusting progressive and modern conceptions of government to the traditional tribal mores-a delicate and difficult task.'

The Department's activities are by no means limited to the reserves, for more than half the native population lives outside the Native Areas, and there its task becomes more complicated and vexatious year by year. The Department spends about $f_{3}$ millions voted by Parliament and administers the Trust Fund for the purchase of additional lands for the Africans: in ten years this amounted to $\ell_{7}$ millions. It is no longer responsible for Native education, since this has now become a charge upon the Consolidated Revenue Fund of the Union and is administered by the Education departments: the expenditure has risen steadily from $£ 605,509$ in $1934-5$ to $£ 3,858,000$ in $1947-8$. But the Department runs its own agricultural colleges and makes a grant of $f_{1} 6,000$ annually to the Fort Hare Native College. It is not directly responsible for health, for which there is a separate department; but it grants $f 80,000$ a year to Mission hospitals and for the training of Native nurses. It spends $f_{1,235,000}$ a year on Old Age and Blind pensions, invalidity grants, and poor-relief. 'It should be noted ', says Dr. D. L. Smit, Deputy Chairman of the Native Affairs Commission, in the first report issued since the conclusion of the war, 'that in no other State in Africa has the full medical course been provided for African students and that in education and social services the Union of South Africa is ahead of any of the northern territories.'

Perhaps only one who, like the present writer, has recently travelled by car 6,000 miles through the Native Areas, can read with understanding and appreciation the voluminous Report of the Native Affairs Department, the Report of the Native Affairs Commission, and the Report of the Social and Economic Planning Council. His tour left three impressions on the mind of the writer: $(a)$ the high quality of the Department's officers; $(b)$ the amazing extent and variety of the work they are doing; and $(c)$ the tremendous task that lies before them. This last point is mainly the subject of the Planning Council's Report. They find, what must be evident to every observer, that the Reserves are rapidly deteriorating, that, in spite of $a$ high mortality rate, the population of the Reserves is increasing at a faster rate than the Reserves can support under existing conditions; and that the Reserves are overstocked. The situation, they say, calls for drastic measures. In these Notes for October 1945 we referred to the Union Government's Twelve Year Plan. Under this scheme, for which Parliament voted fro millions, local planning committees have been at work (the writer met one of them in the Transkei and one in Zululand) and betterment plans have been put in operation. Now the Planning Council proposes to change the constitution of these committees and establish Regional Development Authorities. They advocate the setting up of 